\title{
STRATEGI ADAPTASI NELAYAN DI DESA ALUE NAGA DALAM MENGHADAPI DAMPAK PERUBAHAN IKLIM
}

\author{
Elly Susanti, Mujiburrahmad*, Aurum Sahlida \\ Program Studi Agribisnis, Fakultas Pertanian, Universitas Syiah Kuala \\ Jl. Tgk. Hasan Krueng Kalee No.3, Kopelma Darussalam, Syiah Kuala, Banda Aceh 23111 \\ *Corresponding author: mujiburrahmad@unsyiah.ac.id
}

\begin{abstract}
The purpose of this study is to look at the climate change felt by fishermen in Alue Naga Village and identify economic adaptation strategies undertaken by fishermen in Alue Naga Village in dealing with the effects of climate change. The study was conducted by means of observing the observation of activities carried out directly to the location of the study of the research object using the interview method with a questionnaire that was processed using a Likert Scale and New Seven Tools. The results showed that fishermen in Alue Naga Village strongly agree with the perceived climate change that impacts on activities and affects their survival as fishermen who depend their lives on the sea. Fishermen feel climate change and are aware of the impacts caused by interviews through a questionnaire that found that fishermen have not fully adapted to the impacts of climate change. The improvement strategy using the new seven tools produces the improvement strategy by making efforts to foster a culture of understanding climate change that impacts the fishing community's welfare.
\end{abstract}

Keywords: climate change, fishermen, adaptation, impact

\begin{abstract}
Abstrak : Tujuan penelitian ini adalah untuk melihat adanya perubahan iklim yang dirasakan nelayan di Desa Alue Naga dan mengidentifikasi strategi adaptasi secara ekonomi yang dilakukan nelayan di Desa Alue Naga dalam menghadapi dampak perubahan iklim. Penelitian dilakukan dengan cara observasi yaitu melakukan pengamatan aktivitas yang dilakukan secara langsung ke lokasi penelitian terhadap objek penelitian menggunakan metode wawancara dengan kuesioner yang diolah dengan menggunakan Skala Likert dan New Quality Control Tools. Hasil penelitian menunjukkan nelayan di Desa Alue Naga sangat setuju dengan dirasakan adanya perubahan iklim yang memberikan dampak terhadap kegiatan dan memengaruhi keberlangsungan hidup mereka sebagai nelayan yang menggantungkan hidupnya pada laut. Nelayan merasakan adanya perubahan iklim dan sadar akan dampak yang ditimbulkan menurut hasil wawancara melalui kuesioner didapatkan hasil bahwa nelayan belum sepenuhnya melakukan adaptasi yang dilakukan untuk mengatasi dampak dari perubahan iklim. Strategi perbaikan menggunakan New Quality Control Tools menghasilkan strategi perbaikan dengan melakukan usaha pembinaan agar terciptanya budaya pemahaman perubahan iklim yang berdampak pada peningkatan kesejahteraan masyarakat nelayan.
\end{abstract}

Kata kunci: perubahan iklim, nelayan, adaptasi, dampak

\section{PENDAHULUAN}

Dunia saat ini menghadapi masalah atau fenomena perubahan iklim yang disebabkan oleh adanya pemanasan global (Ahrens, 2007).
Perubahan iklim yang saat ini terjadi menimbulkan dampak yang sangat besar bagi kelangsungan di berbagai bidang kehidupan manusia, demikian halnya pada sektor kelautan dan perikanan. Selain itu, perubahan iklim juga 
berdampak pada aktivitas sosial ekonomi masyarakat di berbagai wilayah, termasuk masyarakat di daerah pesisir khususnya yang berprofesi sebagai nelayan.

Aceh merupakan salah satu provinsi di Indonesia yang memiliki garis pantai terpanjang dengan jumlah $1.660 \mathrm{~km}$ dengan luas wilayah perairan lautnya seluas 295.370 $\mathrm{km}^{2}$ (Maulana, 2014). Dengan jumlah garis pantai yang panjang merupakan suatu potensi besar bagi masyarakat Aceh yang bermata pencaharian sebagai nelayan. Nelayan dengan keadaan ekonomi maupun historisnya telah memanfaatkan sumber daya laut ini secara turun temurun. Namun kondisi saat ini menunjukkan keberadaan sumber daya alam laut dan pesisir yang melimpah belum bisa mengangkat perekonomian nelayan keluar dari garis kemiskinan, ditambah lagi dengan adanya dampak yang ditimbulkan dari perubahan iklim. Beberapa contoh dampak yang ditimbulkan dari perubahan iklim adalah cuaca ekstrim dengan tingkat kecepatan angin, tingkat curah hujan yang tinggi serta gelombang tinggi (Latifa dan Fitranita, 2016).

Salah satu desa nelayan yang ada di Aceh adalah Desa Alue Naga yang memiliki aspek yang cukup baik. Meskipun memiliki segala bentuk potensi dan kemudahan, terdapat ketimpangan antara segala bentuk faktor pendukung dan kondisi masyarakat di lapangan. Nelayan di Desa Alue Naga masih tergolong nelayan tradisional yang memiliki keterbatasan alat tangkap yang menimbulkan masalah bagi nelayan dalam menghadapi dampak perubahan iklim. Dengan keadaan seperti ini menimbulkan satu masalah bagi nelayan dalam menghadapi dampak yang disebabkan oleh adanya perubahan iklim seperti kecepatan angin, curah hujan yang tinggi, ombak besar hingga habitat ikan yang mulai berubah, sehingga jarak nelayan untuk mencari ikan lebih jauh yang mengakibatkan jumlah tangkapan ikan nelayan menurun dan pengeluaran biaya nelayan untuk kegiatan mencari ikan akan terus meningkat.

Patriana dan Satria (2013) melakukan penelitian tentang pola adaptasi nelayan terhadap perubahan iklim di Dusun Cuwaitali, Desa Pamotan, Kecamatan Kalipucang, Kabupaten Ciamis, Jawa Barat. Tujuan dari penelitian ini adalah mengidentifikasi dampak perubahan iklim pada aktivitas nelayan perikanan tangkap dan menganalisis pola adaptasi dan strategi ekonomi yang ditimbulkan oleh perubahan iklim. Metode yang digunakan dalam penelitian ini adalah metode kualitatif eksploratif yang dilengkapi dengan studi literatur. Pengambilan data primer dilakukan melalui wawancara mendalam, observasi, dan Focused Group Discussion (FGD). Hasil penelitian menunjukkan bahwa perubahan iklim berdampak terjadinya perubahan wilayah dan musim penangkapan ikan, meningkatnya resiko melaut akibat gelombang ekstrim dan angin kencang, serta menghambat akses nelayan dalam melaut akibat pendangkalan muara sungai dan gelombang besar. Adaptasi yang dilakukan nelayan antara lain adaptasi iklim melalui "mengejar musim ikan", adaptasi sumber daya pesisir, adaptasi alokasi sumber daya dalam rumah tangga yang meliputi optimalisasi dalam jumlah tenaga kerja dan pola nafkah ganda, dan keluar dari kegiatan perikanan (escaping from fisheries). Nurlaili (2012) melakukan penelitian tentang strategi adaptasi nelayan Bajo menghadapi perubahan iklim studi nelayan Bajo di Kabupaten Sikka, Flores, Nusa Tenggara Timur. Tujuan dari penelitian ini adalah untuk melihat strategi adaptasi nelayan Bajo dalam menghadapi perubahan iklim dengan menggunakan metode penelitian dengan wawancara mendalam, observasi dan FGD. Hasil dari penelitian ini menunjukkan bahwa adanya keterkaitan yang signifikan antara perubahan iklim dengan strategi adaptasi masyarakat nelayan.

Dengan adanya perubahan pada kondisi alam, nelayan diharapkan mampu melakukan perbaharuan teknologi dan melakukan adaptasi (Juana et al., 2013). Adaptasi dilakukan agar kerentanan dapat diatasi dan mengurangi kerugian di sektor perikanan. Adaptasi terhadap perubahan iklim merupakan suatu bentuk respon terhadap rangsangan yang dilakukan untuk mengatasi dampak dari perubahan iklim (Ringler, 2011). Tujuan penelitian ini adalah a) melihat dampak perubahan iklim yang dirasakan nelayan di Desa Alue Naga, dan b) mengidentifikasi strategi adaptasi nelayan di Desa Alue Naga pada aspek ekonomi.

\section{METODE PENELITIAN}

Penelitian ini dilakukan di Desa Alue Naga Kecamatan Syiah Kuala Kota Banda Aceh. 
Desa Alue Naga dipilih berdasarkan letaknya yang berbatasan langsung dengan garis pantai yang masyarakatnya didominasi berprofesi sebagai nelayan. Penelitian ini dilakukan pada Januari 2020. Adapun jenis data yang digunakan pada penelitian ini yaitu data primer dan data sekunder. Data primer adalah data yang diperoleh dari sumber yang bersangkutan dengan penelitian yang dilakukan dengan wawancara atau kuesioner. Data sekunder adalah data yang diperoleh melalui perantara seperti Dinas-dinas atau Instansi lainnya. Dari populasi nelayan di Desa Alue Naga yang berjumlah 102 nelayan diambil 25\% dari populasi dan seluruhnya berjenis kelamin lakilaki. Teknik pengambilan sampel pada penelitian ini menggunakan teknik nonprobability sampling yaitu sampel insidental. Tabel 1 menunjukkan jumlah nelayan yang berada di Desa Alue Naga.

Tabel 1. Populasi dan sampel nelayan di Desa Alue Naga

\begin{tabular}{lcc}
\hline Dusun & $\begin{array}{c}\text { Jumlah } \\
\text { Nelayan }\end{array}$ & Sampel (25\%) \\
\hline Kutaran & 41 & 10 \\
Musafir & 36 & 9 \\
Beunot & 22 & 6 \\
Po Diamat & 3 & 1 \\
\hline Sub Total & 102 & 26 \\
\hline
\end{tabular}

Sumber: Data Primer, 2020

Metode yang digunakan untuk melihat adanya perubahan iklim yang dirasakan nelayan dan mengidentifikasi strategi adaptasi nelayan digunakan metode kualitatif dan kuantitatif. Analisis yang digunakan yaitu:

a. Skala likert yang digunakan untuk mengklasifikasikan variabel yang akan diukur agar tidak terjadi kekeliruan dalam menentukan analisis data.

b. New Quality Control Tools, bagian dari New Seven Tools yang merupakan alat bantu untuk memetakan permasalahan, mengorganisasikan data dengan tampilan visual dan menelusuri berbagai kemungkinan penyebab permasalahan beserta solusinya, mengorganisasikan data agar lebih mudah dipahami, serta menelusuri berbagai kemungkinan penyebab permasalahan

c. Diagram afinitas yang digunakan untuk mengatur sejumlah ide-ide atau pemecahan masalah general ke dalam kelompok pendapat atau kekhawatiran tentang topik tertentu (IS14978: New Seven Tools for Quality Management). Perangkat ini sangat membantu dalam mengidentifikasi pola di dalam data, menyediakan bantuan untuk investigasi atau tindakan yang lebih lanjut.

d. Interrelationship Diagram yang digunakan untuk mengklarifikasi masalah yang kompleks dengan pertimbangan sejumlah penyebab yang mungkin serta menentukan strategi yang tepat untuk setiap penyebab masalah yang berbeda.

e. Tree Diagram yang digunakan untuk memetakan lengkap jalur dan tugas-tugas yang perlu dilakukan dalam rangka untuk mencapai tujuan utama dan tujuan sub terkait diagram pohon digunakan untuk menunjukkan keterkaitan yang antara topik dan elemen komponennya.

f. Biaya produksi nelayan diklasifikasikan menjadi dua yaitu biaya tetap dan biaya variabel.

g. Analisis pendapatan digunakan untuk mengetahui besar pendapatan yang diterima nelayan. Sebelum menghitung pendapatan maka harus diketahui terlebih dahulu penerimaan yang diperoleh nelayan.

\section{HASIL DAN PEMBAHASAN}

\section{Perubahan Iklim}

Perubahan iklim merupakan perubahan pola cuaca yang terjadi dalam rentang waktu yang panjang. Perubahan iklim disini dibatasi dengan tiga indikator iklim yang memengaruhi kinerja atau aktivitas responden yaitu nelayan di Desa Alue Naga seperti perubahan suhu, curah hujan, kecepatan angin dan kerusakan habitat.

\section{Perubahan Suhu Udara}

Perubahan suhu udara berdampak pada meningkatnya suhu air, dan secara tidak langsung akan menambah volume air di samudra yang berimplikasi pada semakin tingginya paras laut. Indikator perubahan suhu udara pada penelitian ini adalah adanya perubahan udara dan dampak perubahan suhu udara. Hasil indeks yang didapatkan dari indikator-indikator tersebut dari 26 responden dapat dilihat pada Tabel 2. 
Tabel 2. Hasil indeks indikator perubahan suhu udara

\begin{tabular}{llccc}
\hline No & \multicolumn{1}{c}{ Pernyataan } & LSkor & Indeks & $\begin{array}{c}\text { Interval } \\
\text { Penilaian }\end{array}$ \\
\hline 1 & Perubahan suhu udara & 112 & $86,15 \%$ & Sangat Setuju \\
2 & Perubahan suhu udara memengaruhi meningkatnya air laut & 112 & $86,15 \%$ & Sangat Setuju \\
3 & Perubahan suhu udara memengaruhi hasil tangkapan & 115 & $88,46 \%$ & Sangat Setuju \\
\hline \multicolumn{2}{c}{ Rata-rata } & & $86,9 \%$ & Sangat Setuju \\
\hline
\end{tabular}

Sumber: Data Primer, 2020

Tabel 3. Hasil indeks indikator perubahan intensitas curah hujan

\begin{tabular}{|c|c|c|c|c|}
\hline No & Pernyataan & $\Sigma$ Skor & Indeks (\%) & $\begin{array}{c}\text { Interval } \\
\text { Penilaian }\end{array}$ \\
\hline 1 & Perubahan intensitas curah hujan & 111 & $85,38 \%$ & Setuju \\
\hline 2 & $\begin{array}{l}\text { Perubahan intensitas curah hujan memengaruhi jarak } \\
\text { tangkap }\end{array}$ & 114 & $87,69 \%$ & Sangat Setuju \\
\hline 3 & $\begin{array}{l}\text { Perubahan intensitas curah hujan memengaruhi hasil } \\
\text { tangkapan }\end{array}$ & 113 & $86,92 \%$ & Sangat Setuju \\
\hline & Rata-rata & & $86,6 \%$ & Sangat Setuju \\
\hline
\end{tabular}

Sumber: Data Primer, 2020

Hasil tersebut didapatkan dari pengolahan indeks perubahan suhu. Berdasarkan kriteria interval pada Tabel 2 nilai indeks yang didapatkan termasuk dalam kategori sangat setuju, maka dapat ditarik kesimpulan bahwa para nelayan di Desa Alue Naga sangat setuju bahwa dirasakan adanya perubahan suhu udara. Salah satu hal yang memengaruhi adanya perubahan suhu adalah pemanasan global yang berdampak pada meningkatnya suhu udara yang dapat menyebabkan naiknya paras laut dan dengan adanya perubahan suhu udara ini berdampak pada berkurangnya hasil tangkapan ikan nelayan (Ulfa, 2018; Soetijono et al., 2020).

\section{Perubahan Intensitas Curah Hujan}

Curah hujan yang tinggi menyebabkan kadar keasaman air laut menurun yang mengakibatkan wilayah atau jarak tangkapan nelayan semakin jauh dan tak terjangkau oleh nelayan kecil yang hanya menggunakan perahu kecil dan alat tangkap seadanya (Ulfa, 2018). Indikator curah hujan pada penelitian ini adalah adanya perubahan intensitas curah hujan dan dampak dari perubahan intensitas curah hujan. Hasil indeks yang didapatkan dari indikatorindikator tersebut dari 26 responden dapat dilihat pada Tabel 3.

Berdasarkan kriteria interval pada Tabel 3 nilai indeks yang didapatkan termasuk dalam kategori sangat setuju dengan nilai indeks $86,66 \%$, maka dapat ditarik kesimpulan bahwa para nelayan di Desa Alue Naga sangat setuju bahwa dirasakan adanya perubahan intensitas curah hujan yang dirasakan nelayan saat ini mengalami fase perubahan. Musim hujan yang dirasakan mengalami perubahan dan terasa lebih lama dan intensitasnya juga meningkat (Widayat et al., 2015).

\section{Perubahan Kecepatan Angin}

Kecepatan angin merupakan kuantitas atmosterik fundamental. Perubahan kecepatan angin disebabkan oleh pergerakan angin dari tekanan tinggi ke tekanan rendah dan terjadi karena adanya perubahan suhu udara sehingga menyebabkan gelombang (Lakitan, 2002). Indikator perubahan kecepatan angin pada penelitian ini adalah adanya perubahan kecepatan angin dan dampak dari perubahan kecepatan angin. Hasil indeks yang didapatkan dari indikator-indikator tersebut dari 26 responden dapat dilihat pada Tabel 4.

Berdasarkan kriteria interval penilaian pada Tabel 3, nilai indeks 91,53\% termasuk dalam kategori sangat setuju. Dari tabel diatas maka dapat ditarik kesimpulan bahwa para nelayan yang berada di Desa Alue Naga sangat setuju dengan adanya perubahan kecepatan angin yang menyebabkan gelombang besar yang mengganggu aktivitas serta menyebabkan rendahnya hasil tangkapan para nelayan.

\section{Kerusakan Habitat}

Kerusakan habitat adalah terganggunya atau rusaknya suatu habitat ekosistem makhluk 
Tabel 4. Hasil indeks indikator perubahan kecepatan angin

\begin{tabular}{|c|c|c|c|c|}
\hline No & Pernyataan & $\Sigma$ Skor & Indeks $(\%)$ & Interval Penilaian \\
\hline 1 & Perubahan kecepatan angin & 119 & $91,53 \%$ & Sangat Setuju \\
\hline 2 & Perubahan kecepatan angin memengaruhi gelombang & 119 & $91,53 \%$ & Sangat Setuju \\
\hline 3 & $\begin{array}{l}\text { Perubahan kecepatan angin memengaruhi hasil } \\
\text { tangkapan }\end{array}$ & 119 & $91,53 \%$ & Sangat Setuju \\
\hline & Rata-rata & & $91,5 \%$ & Sangat Setuju \\
\hline
\end{tabular}

Sumber: Data Primer, 2020

Tabel 5. Interval penilaian indikator kerusakan habitat

\begin{tabular}{|c|c|c|c|c|}
\hline No & Pernyataan & $\Sigma$ Skor & Indeks $(\%)$ & Interval Penilaian \\
\hline 1 & Kerusakan habitat & 106 & $81,53 \%$ & Setuju \\
\hline 2 & Kerusakan habitat memengaruhi hasil tangkapan & 106 & $81,53 \%$ & Setuju \\
\hline & Rata-rata & & $81,5 \%$ & Setuju \\
\hline
\end{tabular}

Sumber: Data Primer, 2020

hidup yang menimbulkan suatu masalah bagi makhluk hidup. Kerusakan habitat salah satunya diakibatkan karena adanya perubahan iklim. Indikator kerusakan habitat pada penelitian ini adalah adanya kerusakan habitat dan dampak dari kerusakan habitat (Sagala, 2016). Hasil indeks yang didapatkan dari indikator-indikator tersebut dari 26 responden dapat dilihat pada Tabel 5.

Berdasarkan kriteria interval penilain pada Tabel 5, nilai indeks sebesar 81,53\% maka dapat ditarik kesimpulan bahwa dengan adanya perubahan iklim menyebabkan habitat ikan rusak seperti rusaknya terumbu karang dan lain sebagainya, dengan begitu secara tidak langsung akan memengaruhi hasil tangkapan nelayan.

Hasil penelitian ini selaras dengan penelitian terdahulu (Patriana dan Satria, 2013) yang menunjukkan bahwa adanya perubahan iklim berdampak pada terjadinya perubahan wilayah dan musim penangkapan ikan, serta menghambat akses nelayan dalam melaut akibat pendangkalan muara sungai dan kerusakan terumbu karang. Dengan keadaan tersebut habitat ikan terganggu atau rusak yang menyebabkan hasil tangkapan nelayan khususnya nelayan tradisional yang memiliki keterbatasan alat tangkap akan berkurang.

\section{Strategi Adaptasi Nelayan}

Dampak perubahan iklim terhadap aktivitas nelayan sudah banyak diketahui secara luas, dalam beberapa waktu kedepan perubahan iklim akan terus berlangsung dan akan terus memengaruhi aktivitas nelayan dalam mencari ikan di laut. Dampak dari adanya perubahan iklim ini antara lain yaitu gelombang tinggi, jumlah ikan terbatas, jarak tangkap semakin jauh dan cuaca buruk yang tidak dapat diprediksi. Dampak tersebut tentu saja sangat memengaruhi hasil tangkapan dan keadaan ekonomi nelayan. Adapun salah satu upaya yang harus dilakukan nelayan di Desa Alue Naga antara lain adalah adaptasi secara ekonomi.

\section{Adaptasi Secara Ekonomi}

Adaptasi secara ekonomi adalah cara yang dilakukan nelayan untuk dapat mengatasi dan menyesuaikan diri terhadap dampak dari perubahan iklim melalui kegiatan yang berkaitan langsung dengan kegiatan ekonomi nelayan seperti pengendalian pendapatan nelayan serta mengembangkan usaha nelayan dalam menambah jumlah pendapatan. Adapun beberapa faktor yang dapat dijadikan indikator terhadap keberhasilan nelayan dalam melaksanakan adaptasi terhadap perubahan iklim yang berdampak terhadap perekonomian nelayan yaitu, pendidikan, tingkat pendapatan, teknologi dan pengaruh cuaca.

Berdasarkan kriteria interval penilaian pada Tabel 6, nilai indeks yang didapatkan sebesar 20,38\% dan termasuk dalam kategori sedikit melakukan, maka dapat ditarik kesimpulan bahwa para nelayan di Desa Alue Naga masih sangat kurang paham tentang pentingnya suatu pendidikan atau pengetahuan tentang hal-hal yang berkaitan langsung dengan kegiatan mereka sebagai nelayan. Pada dasarnya pendidikan merupakan suatu pembelajaran tentang suatu hal yang berkaitan dengan apa yang dibutuhkan, dengan tujuan 
Tabel 6. Interval penilaian indikator pendidikan

\begin{tabular}{clcccc}
\hline No & \multicolumn{1}{c}{ Pernyataan } & ISkor & Indeks(\%) & Interval Penilaian \\
\hline 1 & $\begin{array}{l}\text { Mengikuti kegiatan pelatihan seputar } \\
\text { tentang profesi sebagai nelayan }\end{array}$ & 27 & $20,76 \%$ & Sedikit Melakukan \\
2 & $\begin{array}{l}\text { Melakukan kegiatan sesama nelayan } \\
\text { dalam menentukan kawasan penangkapan }\end{array}$ & 26 & $20 \%$ & Sedikit Melakukan \\
\hline \multicolumn{2}{c}{ Rata-rata } & $20,38 \%$ & Sedikit Melakukan \\
\hline
\end{tabular}

Sumber: Data Primer, 2020

Tabel 7. Interval penilaian indikator endapatan

\begin{tabular}{llccc}
\hline No & \multicolumn{1}{c}{ Pernyataan } & ISkor & Indeks (\%) & Interval Penilaian \\
\hline 1 & $\begin{array}{l}\text { Menggunakan sumber tangkapan lain } \\
\text { selain dari laut }\end{array}$ & 229 & $22,30 \%$ & Sedikit Melakukan \\
& $\begin{array}{l}\text { Melakukan kegiatan diluar dari kegiatan } \\
\text { nelayan untuk menambah pendapatan }\end{array}$ & 330 & $23,07 \%$ & Sedikit Melakukan \\
3 & Melakukan sistem nafkah ganda & 335 & $26,92 \%$ & Sedikit Melakukan \\
& Melakukan pengendalian pendapatan & 445 & $34,61 \%$ & Sedikit Melakukan \\
\hline \multicolumn{2}{r}{ Rata-rata } & & $26,72 \%$ & Sedikit Melakukan \\
\hline
\end{tabular}

Sumber: Data Primer, 2020

agar dapat mencerdaskan dan mengembangkan potensi di dalam diri nelayan (Kolopaking, 2014). Dengan begitu dapat meningkatkan kesejahteraan hidup nelayan.

Berdasarkan kriteria interval pada Tabel 7 nilai indeks yang didapatkan sebesar $26,72 \%$ termasuk dalam kategori sedikit melakukan, maka dapat ditarik kesimpulan bahwa sebagian besar responden merupakan profesi tetap atau profesi tunggal yaitu sebagai seorang nelayan, sehingga tingkat ketergantungan dengan hasil laut sangat tinggi. Responden masih sedikit melakukan strategi adaptasi untuk tidak bergantung penuh pada kondisi laut dengan cara beralih atau menambah sumber pendapatan dengan tujuan menambah pundipundi pendapatan. Rata-rata pendapatan yang didapatkan responden yaitu nelayan/bulan dapat dilihat pada Tabel 8 .

Tabel 8. Analisis rata-rata pendapatan nelayan

\begin{tabular}{ll}
\hline \multicolumn{1}{c}{ Uraian } & Rata-Rata (Rp) \\
\hline A. TC (Total Cost) & \\
Biaya Tetap (FC) & Rp2.214.000 \\
Biaya Tidak Tetap (VC) & Rp960.000 \\
Total Biaya (FC+VC) & Rp3.174.000 \\
B. TR (Total Revenue) & \\
Total Penerimaan (QxP) & Rp5.511.000 \\
C. Pendapatan & \\
Total Pendapatan (TR-TC) & Rp2.337.000 \\
\hline Sumber: Data Primer, 2020 &
\end{tabular}

Pada Tabel 8 dapat dilihat bahwa ratarata pendapatan nelayan sebesar Rp2.337.000/bulan. Dengan pendapatan sebesar Rp2.337.000/bulan untuk menghidupkan keluarga merupakan nominal yang sangat kecil. Dengan penghasilan tersebut seorang nelayan harus mampu memenuhi kebutuhan keluarganya mulai dari biaya makan, sekolah anak dan hal-hal lainnya.

Berdasarkan kriteria interval pada Tabel 9 nilai indeks yang didapatkan sebesar $20 \%$ termasuk dalam kategori sedikit melakukan, maka dapat ditarik kesimpulan bahwa para nelayan di Desa Alue Naga masih sedikit melakukan kegiatan nelayan yang berkaitan tentang teknologi. Teknologi merupakan suatu alat yang dapat membantu dan memudahkan kegiatan nelayan untuk mencari ikan. Tidak adanya teknologi memberikan dampak tersendiri terhadap kegiatan nelayan. Dengan keadaan sekarang teknologi itu sangat dibutuhkan diberbagai bidang profesi tak terkecuali pada profesi sebagai nelayan.

Berdasarkan kriteria interval pada Tabel 10 nilai indeks yang didapatkan sebesar $86.65 \%$ termasuk dalam kategori sangat setuju, maka dapat ditarik kesimpulan bahwa nelayan di Desa Alue Naga sangat setuju dengan adanya perubahan iklim dan memberikan dampak yang cukup besar terhadap aktivitas dan hasil tangkapan mereka sebagai nelayan. Perubahan iklim adalah salah satu hal yang sangat memengaruhi kegiatan nelayan dan 
Tabel 9. Interval penilaian indikator teknologi

\begin{tabular}{clccc}
\hline No & Pernyataan & $\Sigma$ Skor & Indeks (\%) & Interval Penilaian \\
\hline 1 & $\begin{array}{l}\text { Menggunakan teknologi prakiraan cuaca dalam } \\
\text { menjalankan aktivitas nelayan }\end{array}$ & 26 & $20 \%$ & Sedikit Melakukan \\
2 & $\begin{array}{l}\text { Melakukan teknologi terbarukan dalam } \\
\text { menjalankan aktivitas nelayan } \\
\text { Perubahan kecepatan angin memengaruhi hasil } \\
\text { tangkapan }\end{array}$ & 264 & $20 \%$ & Sedikit Melakukan \\
\hline Rata-rata & & $27,53 \%$ & Ada Melakukan \\
\hline
\end{tabular}

Sumber: Data Primer, 2020

Tabel 10. Interval penilaian indikator pengaruh cuaca

\begin{tabular}{llccc}
\hline No & \multicolumn{1}{c}{ Pernyataan } & $\Sigma$ Skor & Indeks (\%) & Interval Penilaian \\
\hline 1 & Perubahan suhu udara & 113 & $86,91 \%$ & Sangat Setuju \\
2 & Perubahan intensitas curah hujan & 112 & $86,66 \%$ & Sangat Setuju \\
3 & Kecepatan angin & 119 & $91,53 \%$ & Sangat Setuju \\
4 & Kerusakan habitat & 106 & $81,53 \%$ & Sangat Setuju \\
\hline & & & $86,65 \%$ & Sangat Setuju \\
\hline
\end{tabular}

Sumber: Data Primer, 2020

memberikan dampak negatif bagi aktivitas nelayan (Sudiyono, 2016).

\section{Strategi Optimasi Adaptasi Nelayan Terhadap Perubahan Iklim}

Berdasarkan hasil analisis skala likert, didapatkan bahwa dalam prosesnya terdapat beberapa faktor yang menyebabkan terjadinya kegagalan implementasi adaptasi nelayan di Desa Alue Naga, Banda Aceh terhadap perubahan iklim diantaranya Faktor Manusia (SDM), Faktor Alam, Faktor Teknologi, dan Faktor Metode. Melalui metode New Seven Tools peneliti mencoba mengelaborasi (breakdown) beberapa strategi yang dapat dilakukan agar nelayan di desa Alue Naga, Banda Aceh dapat terus menjalani kehidupan dengan limpahan kesejahteraan karena berhasil melaksanakan strategi adaptasi terhadap perubahan iklim.

\section{Affinity Diagram}

Hasil diskusi dengan pemangku kepentingan Nelayan Alue Naga dan pengamatan langsung pada proses kegiatan penangkapan ikan didapatkan beberapa faktor yang menyebabkan gagalnya adaptasi nelayan yang berdampak pada keberlangsungan hidup masyarakat yang diwakili oleh manusia, alam, teknologi, dan metode.

Affinity diagram digunakan sebagai bagian dari strategi perbaikan yang menyajikan hasil penjabaran solusi perbaikan dari faktor penyebab kegagalan adaptasi nelayan.
Gambar 1 menunjukkan bahwa penyebab kegagalan adaptasi nelayan ada empat yaitu manusia, alam, teknologi dan manajemen/ metode. Dimana masing-masing mempunyai variabel yang menyebabkan kegagalan adaptasi nelayan dan selanjutnya akan dicari hubungannya antara satu variabel dengan yang lainnya. Misalnya kegagalan adaptasi yang disebabkan oleh manusia atau nelayan itu sendiri karena rendahnya tingkat pendidikan, kurangnya pelatihan dan peningkatan skill nelayan serta regenerasi profesi nelayan semakin rendah hal ini sesuai dengan penelitian dari Rahman (2019).

\section{Interrelationship Diagram}

Interrelationship diagram yang menunjukkan hubungan antar variable penyebab kegagalan adaptasi nelayan. Proses pembuatan diagram didasarkan pada aliran tanda panah dari setiap variabel penyebab kegagalan adaptasi nelayan. Variabel dengan aliran panah keluar terbanyak diindikasikan sebagai akar permasalahan, sementara variabel dengan aliran tanda panah masuk terbanyak memungkinkan sebagai solusi yang digambarkan pada Gambar 2.

Gambar 2 menunjukkan, terdapat beberapa variabel yang berkaitan dengan penyebab-penyebab kegagalan adaptasi. Anak panah pada diagram tersebut menunjukkan sebab akibat dari variabel, dimana panah berarah dari penyebab menuju ke akibatnya. Interrelationship Diagram menunjukkan bahwa variabel perubahan ekosistem laut (iklim laut) 
KEGAGALAN ADAPTASI NELAYAN

\begin{tabular}{|l|}
\hline \multicolumn{2}{|c|}{ MANUSIA } \\
\hline \\
\hline $\begin{array}{l}\text { Rendahnya } \\
\text { tingkat } \\
\text { pendidikan }\end{array}$ \\
- Kurangnya \\
pelatihan dan \\
peningkatan skill \\
nelayan \\
- Regenerasi \\
profesi nelayan \\
semakin rendah
\end{tabular}

\begin{tabular}{|l|}
\hline \multicolumn{2}{|c|}{ ALAM } \\
\hline \\
\hline $\begin{array}{l}\text { - Perubahan suhu } \\
\text { muka air laut }\end{array}$ \\
- Peningkatan \\
unpredictable \\
intensitas hujan \\
- Perubahan \\
kecepatan \\
pergerakan \\
angin \\
- Kerusakan \\
habitat \\
ekosistem laut
\end{tabular}

\begin{tabular}{|c|}
\hline TEKNOLOGI \\
\hline \\
\hline $\begin{array}{l}\text { - Kepemilikan alat } \\
\text { masih milik } \\
\text { pihak lain }\end{array}$ \\
\hline $\begin{array}{l}\text { - Tidak didukung } \\
\text { teknologi Sonar, } \\
\text { Jaring dll }\end{array}$ \\
\hline $\begin{array}{l}\text { - Kapasitas } \\
\text { jangkauan } \\
\text { perahu terbatas }\end{array}$ \\
\hline $\begin{array}{l}\text { - Tidak adanya } \\
\text { teknologi added } \\
\text { value }\end{array}$ \\
\hline
\end{tabular}

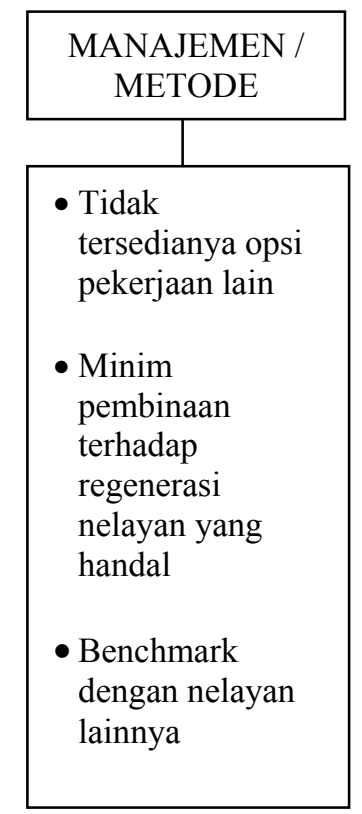

Gambar 1. Affinity diagram

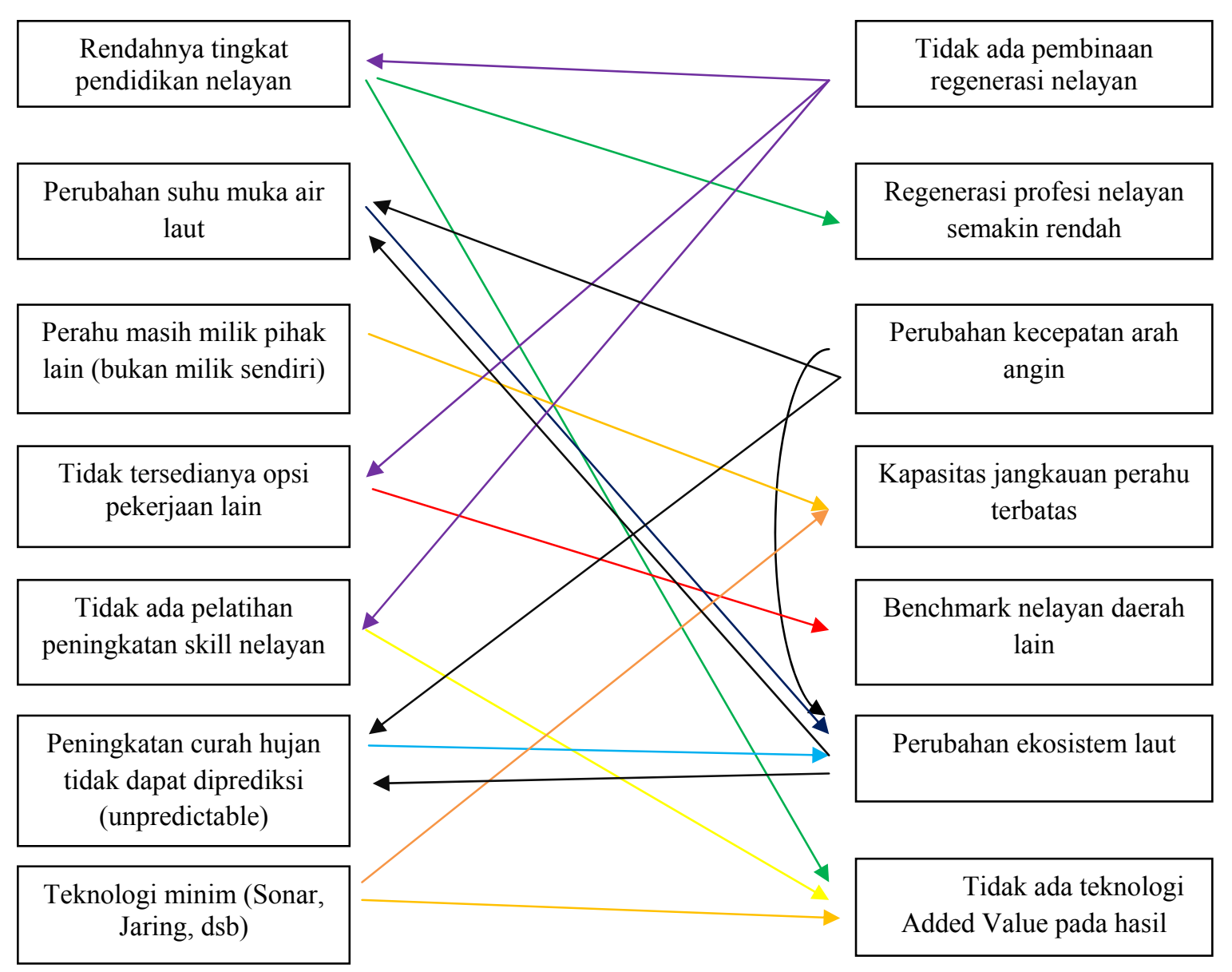

Gambar 2. Interrelationship diagram 


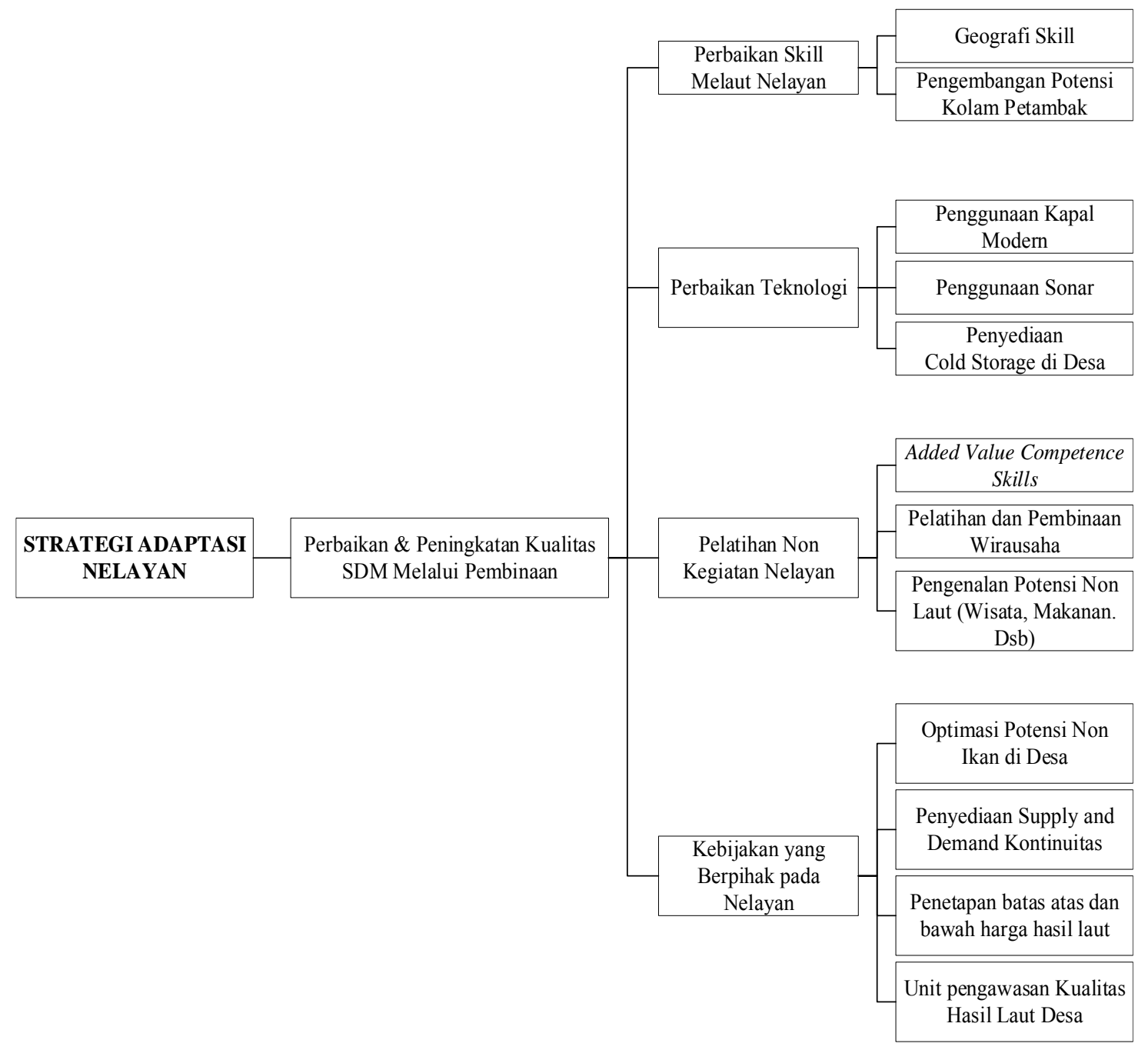

Gambar 3. Tree diagram

merupakan variabel yang disinyalir menjadi akar penyebab dari kerusakan bahan baku ikan dan pelaksanaan pembinaan kepada nelayan menjadi solusi dari permasalahan tersebut.

\section{Tree Diagram}

Tree diagram digunakan untuk memecahkan suatu konsep atau aktivitas-aktivitas secara lebih terperinci ke dalam sub-sub komponen atau tingkat yang lebih rendah dan terperinci lagi. Berdasarkan hasil wawancara dan diskusi dengan pihak nelayan dan stakeholder didapatkan beberapa informasi mengenai beberapa alternatif yang dapat dilakukan untuk adaptasi nelayan beserta breakdown untuk setiap alternatif berdasarkan levelnya.

Gambar 3 menunjukkan bahwa untuk adaptasi nelayan terdapat beberapa alternatif pencapaian yaitu menguatkan kemampuan nelayan, perbaikan kondisi peralatan dan penggunaan metode yang sesuai. Dimana dari masing-masing alternatif tersebut dikembangkan lagi menjadi beberapa level yang merupakan solusi untuk melakukan improvement.

\section{KESIMPULAN}

Terjadinya perubahan iklim di Desa Alue Naga yang memberikan dampak negatif terhadap kegiatan nelayan seperti kurangnya hasil tangkapan, nelayan di Desa Alue Naga hanya sedikit yang melakukan adaptasi secara ekonomi terhadap perubahan iklim karena belum memahami keterkaitan tiap segmen adaptasi yang akan berdampak langsung terhadap kesejahteraan hidup nelayan serta strategi perbaikan menggunakan new seven 
tools menghasilkan strategi perbaikan dengan melakukan usaha pembinaan agar terciptanya budaya pemahaman perubahan iklim yang berdampak pada peningkatan kesejahteraan masyarakat nelayan.

Berdasarkan hasil penelitian yang didapatkan, beberapa saran yang dapat diusulkan yang pertama bagi nelayan, pemerintah, dan stakeholder lainnya pelaksanaan adaptasi nelayan menjadi mutlak dilakukan dan harus didukung dengan berbagai macam faktor yang akan membantu masyarakat nelayan keluar dari kesulitan dalam pencarian ikan dan yang kedua bagi penelitian selanjutnya, pengumpulan informasi yang baik terhadap proses adaptasi ekonomi sangat diperlukan. Penentuan pembinaan dan dukungan keilmuan kepada nelayan menjadi faktor utama keberhasilan strategi adaptasi nelayan menghadapi perubahan iklim saat ini.

\section{DAFTAR PUSTAKA}

Ahrens, D. (2007). Meteorologi Today An Introduction To Weather, Climate and The Environment. USA: Thompson Higher Education.

Soetijono, I. K., Martiasari, A., \& Kurniawan, V. (2020). Strategi adaptasi nelayan dalam menghadapi perubahan ekologis di Pantai Cemara Banyuwangi. Prosiding Konferensi Nasional Hak Asasi Manusia, Kebudayaan dan Tujuan Pembangunan Berkelanjutan Indonesia pada Masa Pandemi COVID-19: Tantangan untuk Keilmuan Hukum dan Sosial, 393-424.

Juana, J., Kahaka, Z., \& Okurut, F. (2013). Farmers' perceptions and adaptations to climate change in Sub-Sahara Africa: A Synthesis of empirical studies and implications for public policy in African Agriculture. Agricultural Science Journal, 5(4), 121-135. https://doi.org/10.5539/jas.v5n4p121.

Kolopaking, L. M. (2014). Adaptasi perubahan iklim komunitas desa: Studi kasus di kawasan pesisir utara Pulau Ambon. Komunitas: International Journal of
Indonesian Society and Culture, 6(1), $57-69$.

Lakitan, B. (2002). Dasar-Dasar Klimatologi. Jakarta: Raja Grafindo Persada.

Latifa, A. \& Fitranita. (2016). Strategi bertahan hidup perempuan dalam menghadapi dampak perubahan iklim. Jurnal Kependudukan Indonesia, 8(1), 53-63.

Ulfa, M. (2018). Persepsi masyarakat nelayan dalam menghadapi perubahan iklim (Ditinjau dalam aspek sosial ekonomi). Jurnal Pendidikan Geografi, 23(1), 4149.http://dx.doi.org/10.17977/um017v23i $12018 \mathrm{p} 041$.

Maulana, H. (2014). Pengembangan Komoditas Mangrove Bagi Wilayah Pesisir Provinsi Aceh. Banda Aceh: Universitas Syiah Kuala.

Nurlaili, N. (2012). Strategi adaptasi nelayan Bajo menghadapi perubahan iklim: Studi nelayan Bajo di Kabupaten Sikka, Flores, Nusa Tenggara Timur. Jurnal Masyarakat dan Budaya, 14(3), 599624.

Patriana, R. \& Satria, A. (2013). Pola adaptasi nelayan terhadap perubahan iklim: Studi kasus nelayan Dusun Ciawitali, Desa Pamotan, Kecamatan Kalipucang Kabupaten Ciamis, Jawa Barat. J. Sosek $K P, \quad 8(1), 11-23$. http://dx.doi.org/10. 15578/jsekp.v8i1.1191.

Rahman, M. S. (2019). Pekerjaan alternatif sebagai strategi adaptasi nelayan terhadap perubahan iklim (Studi Kasus di Kecamatan Paiton, Kabupaten Probolinggo). HABITAT, 30(1), 1-7.

Ringler, C. B. (2011). How can African Agriculture Adapt to Climate Change: Insights from Ethiopia and South Africa. Washington, DC: IFPRI. Retrieved from https://media.africaportal.org/documents/ Research_Brief_Series_15.pdf.

Sagala, S. A. (2016). Strategi adaptasi nelayan terhadap dampak perubahan lingkungan (Studi Kasus: Pemanfaatan teknologi 
Susanti, E., Mujiburrahmad, Sahlida, A. : Strategi Adaptasi Nelayan di Desa ....

penangkapan ikan laut). Jurnal Penataan Ruang, 11(2), 22-35.

Sudiyono, S. (2016). Strategi adaptasi nelayan Desa Tanjung Berakit dalam menghadapi perubahan iklim. Jurnal Masyarakat dan Budaya, 18(2), 107-125.
Widayat, H. P., Anhar, A., \& Baihaqi, A. (2015). Dampak pengaruh perubahan iklim terhadap produksi, kualitas hasil dan pendapatan petani kopi Arabika di Aceh Tengah. Jurnal Agrisep, 16(2), 816. 